\title{
On-farm comparison of pasture production in relation to rainfall in Central Otago
}

\author{
J.K. KEARNEY ${ }^{1}$, D.J. MOOT ${ }^{2}$ and K.M. POLLOCK ${ }^{2}$ \\ ${ }^{1}$ Greenfield Agribusiness, PO Box 642, Blenheim \\ ${ }^{2}$ Faculty of Agriculture and Life Sciences, PO Box 74, Lincoln University
}

Juliekearney@greenfield.co.nz

\begin{abstract}
Dry matter (DM) yields of unimproved resident browntop-dominant pasture on three Central Otago dryland farms was $<1.5 \mathrm{t} / \mathrm{ha} /$ year from 2008-2010. An intensive pasture renewal programme over $>18000$ ha applied lime to increase soil $\mathrm{pH}$ to $\geq 5.8$ and reduce aluminium to $<1.5 \mathrm{mg} / \mathrm{kg}$. The resident vegetation was sprayed in autumn before spring drilling of perennial ryegrass/white clover pastures or lucerne monocultures. After renovation, ryegrass pastures yielded 3.1-5.3 t $\mathrm{DM} / \mathrm{ha}$ and lucerne produced 4.2-8.4 t DM/ha. Yields of improved pastures were affected by the soil moisture stored during autumn and winter and spring rainfall. Together these gave a water use efficiency of $\sim 16.0 \mathrm{~kg}$ $\mathrm{DM} / \mathrm{ha} / \mathrm{mm}$ for lucerne compared with $3.5 \mathrm{~kg} \mathrm{DM} / \mathrm{ha} /$ $\mathrm{mm}$ for browntop dominant pasture. Quantifying and explaining yield improvements on-farm in relation to rainfall and soil moisture deficits provide a transferable basis for interpretation of results at other sites.

Keywords: browntop, Agrostis capillaries, cocksfoot, Dactylis glomerata, tall fescue, Festuca arundinacea, lucerne, Medicago sativa, perennial ryegrass, Lolium perenne, white clover, Trifolium repens
\end{abstract}

\section{Introduction}

In the driest areas of New Zealand, such as Central Otago, yields from resident grass dominant pastures are typically low (Radcliffe \& Baars 1987). Dryland farmers in these regions must adopt species and systems that will convert the limited amount of annual rainfall into high quality forage. Perennial ryegrass (Lolium perenne) is typically the most commonly sown grass species, but lack of dry matter (DM) production and persistence have recently seen its suitability for dryland areas questioned (Avery et al. 2008; Brown et al. 2006). These authors showed that lucerne (Medicago sativa) has an advantage in dryland environments, because it can produce high quality forage and responds rapidly to summer rainfall.

Moot et al. (2008) provided the physiological basis for the yield advantages reported for lucerne. Seasonal differences highlighted the importance of spring for DM production and water use efficiency (WUE) on dryland farms. Specifically, lucerne had a spring WUE of $24 \mathrm{~kg}$ $\mathrm{DM} / \mathrm{ha} / \mathrm{mm}$ and produced $6.1 \mathrm{t} \mathrm{DM} / \mathrm{ha}$ from $250 \mathrm{~mm}$ of stored soil water and rainfall. This compared with $2.8 \mathrm{t}$ $\mathrm{DM} /$ ha of perennial ryegrass/white clover pasture at 11 $\mathrm{kg} \mathrm{DM} / \mathrm{ha} / \mathrm{mm}$. Data that were easily collected on-farm are used in this paper to compare pasture production and water use efficiency from a commercial situation.

Since 2007, Greenfield Agribusiness have been developing dryland properties in the Central Otago and Strath Taieri regions. Traditionally, cold winters and low annual rainfall have meant these regions have been used for fine wool and store lamb production. In these extensive systems, pasture renovation and capital fertiliser applications are limited by financial constraints and unpredictable returns. For development in these regions, quantification of the benefits gained through the correction of soil nutrient status and the introduction of suitably adapted pasture species is required. In many cases perennial ryegrass/white clover pastures have been tried but failed to persist while lucerne has been grown to be conserved. Here we quantify yields of improved and resident pastures measured on three different properties and interpret these in relation to annual and seasonal rainfall.

\section{Methods}

\section{Site description}

A pasture improvement programme, has been undertaken across 25000 ha of dryland farmland in the South Island of New Zealand, with 18000 ha in the Maniototo and Strath Taieri areas of Otago. The three properties in this region that were used in this study are described in Table 1. Long-term air temperature and rainfall for their locations are presented in Table 2.

Initially resident pastures on all the properties were dominated (60-90\%) by browntop (Agrostis capillaris), with lesser contributors from hieracium (Hieracium pilosella), sweet vernal (Anthoxanthum odoratum), perennial ryegrass (Lolium perenne). Minor species $(<5 \%)$ included annual weed grass species (Bromus spp.), white (Trifolium repens) and suckling (Trifolium dubium) clovers, sorrel (Rumex acetosella), yarrow (Achillea millefolium) and Californian thistle (Cirsium arvense). Data for this study came from flat-to-rolling 
Table 1 Site description for three Otago farms used in this study.

\begin{tabular}{llll}
\hline Description & Hills Creek Station $(\mathrm{HC})$ & Huntleigh Station $(\mathrm{HU})$ & $\begin{array}{l}\text { Styx Station } \\
(\mathrm{SX})\end{array}$ \\
\hline Location & $10.8 \mathrm{~km}$ north of Oturehua & $14.6 \mathrm{~km}$ SE of Middlemarch & $11.4 \mathrm{~km}$ west of Paerau \\
Area $(\mathrm{ha})$ & 3927 & 6402 & 7533 \\
Altitude range $(\mathrm{m})$ & $440-860$ & $140-620$ & $560-890$ \\
Soil Types & Yellow-Grey & Yellow-Grey & Yellow-Grey \\
(Soil Bureau Bulletin No. 27) & Yellow Brown & Yellow-Brown & Yellow-Brown \\
& & & Gley Recent \\
& & & Recent \\
\hline
\end{tabular}

Table 2 January, July and annual temperature means $\left({ }^{\circ} \mathrm{C}\right)$ and rainfall $(\mathrm{mm})$ from selected NIWA climate stations near the monitored farms for the period $2000-2010$.

\begin{tabular}{lccccccccccc}
\hline & \multicolumn{3}{c}{$\begin{array}{c}\text { January } \\
\end{array}$} & \multicolumn{3}{c}{ Temperature } & & \multicolumn{2}{c}{ July } & & \multicolumn{2}{c}{$\begin{array}{c}\text { Annual } \\
\text { Temprature }\end{array}$} \\
\hline NIWA Station & $\max$ & Mean & min & Rain & max & Mean & min & Rain & Mean & Rain \\
\hline Lauder & 20.7 & 13.7 & 6.8 & 94.6 & 5.1 & 0.5 & -4.1 & 10.0 & 10.0 & 384 \\
Middlemarch & 19.9 & 13.2 & 6.6 & 58.2 & 9.0 & 2.9 & -3.2 & 36.4 & 10.2 & 364 \\
Ranfurly & 19.6 & 12.7 & 5.9 & 64.2 & 6.4 & 1.0 & -4.3 & 29.0 & 9.0 & 432 \\
\hline
\end{tabular}

*Altitudes and distance to monitored farms are: Lauder $375 \mathrm{~m}$ and $22 \mathrm{~km}$ SW of Hills Creek; Middlemarch $213 \mathrm{~m}, 13 \mathrm{~km}$ NW of Huntleigh and 26 km ESE of Styx; Ranfurly 450 m, 52 km NNW of Huntleigh, 39 km NNE of Styx and 24 km SE of Hills Creek.

Table 3 Typical $15 \mathrm{~cm}$ soil test results for pre (2008) and post (2010) fertiliser applications from three Central Otago farms.

\begin{tabular}{lcccccccc}
\hline & Month & $\mathrm{pH}$ & $\begin{array}{c}\text { Olsen P (ug/ } \\
\mathrm{ml})\end{array}$ & $\begin{array}{c}\text { Calcium } \\
(\mathrm{QTU})\end{array}$ & $\begin{array}{c}\text { Magnesium } \\
(\mathrm{QTU})\end{array}$ & $\begin{array}{c}\text { Potassium } \\
(\mathrm{QTU})\end{array}$ & $\begin{array}{c}\text { Sulphur } \\
(\mathrm{ug} / \mathrm{g})\end{array}$ & $\begin{array}{c}\text { Aluminium } \\
(\mathrm{mg} / \mathrm{kg})\end{array}$ \\
\hline Hills Creek Pre- & Mar & 5.2 & 10 & 6 & 21 & 5 & 14 & 2.6 \\
Post- & Mar & 5.8 & 19 & 7 & 23 & 9 & 31 & 0.9 \\
Huntley Pre- & Apr & 5.2 & 10 & 5 & 17 & 5 & 1 & 6.3 \\
Post- & Mar & 6.0 & 18 & 10 & 17 & 4 & 25 & 1.5 \\
Styx - Pre & Mar & 5.2 & 13 & 3 & 31 & 13 & 3 & 5.7 \\
Post- & Mar & 6.1 & 29 & 10 & 19 & 13 & 23 & 1.1 \\
\hline
\end{tabular}

paddocks that were developed by tractor. Soil tests were conducted in 2008, before pasture renewal, and were repeated in 2010 (Table 3 ).

At least $250 \mathrm{~kg} / \mathrm{ha}$ of superphosphate as capital fertiliser and 3-5 t lime/ha were broadcast onto resident vegetation. Existing pastures were sprayed in autumn (April/May), particularly to control browntop with glyphosate at $6 \mathrm{~L} /$ ha of $360 \mathrm{~g}$ a.i./L, and $40 \mathrm{~g}$ a.i./ha tribenuron methyl (Granstar), with caution in relation to the lime applied in the previous 2 months (this can increase the residual effect of the chemical), and 150 $\mathrm{ml} /$ ha of an organosilicone penetrant. The paddocks were fallowed over winter, before a second spray with the equivalent of $4 \mathrm{~L} / \mathrm{ha}$ of $360 \mathrm{~g}$ a.i./ha of glyphosate, $192 \mathrm{ml} \mathrm{a.i./ha}$ of chlorpyrifos insecticide for control of springtails (Collembola spp.), and $150 \mathrm{ml} / \mathrm{ha}$ of the organosilicone penetrant in the early spring (September/ October). If required, tribenuron methyl was added to control yarrow, fathen, shepherd's purse or Californian thistle. Paddocks were then left for 3-14 days before seed was direct-drilled with a triple-disc drill with 100 $\mathrm{kg} /$ ha of serpentine super. 'Grasslands Kaituna' lucerne (Medicago sativa) was sown at $10 \mathrm{~kg} / \mathrm{ha}$ of superstriketreated seed. Perennial ryegrass (Lolium perenne) with the AR37 endophyte was direct-drilled into $10 \%$ of the farms at $25 \mathrm{~kg} /$ ha with $2 \mathrm{~kg} / \mathrm{ha}$ of 'Tekapo' cocksfoot and $3 \mathrm{~kg} / \mathrm{ha}$ of 'Tahora' white clover. The perennial ryegrass/white clover mixture was sown in November 2008 at Hills Creek and The Styx and in November 2009 at Huntleigh.

After sowing, all lucerne paddocks were left to flower before their first grazing. All ryegrass/white clover pastures were left 6-8 weeks before their first grazing. No mechanical harvesting of forage occurred in the first year on any paddock. After the first winter, the pastures were grazed or mechanically harvested as 
required. All lucerne paddocks were rotationally grazed for 3-10 days and then spelled for 35-42 days. Each lucerne paddock was left to flower every year at some stage in January or February to build up root reserves (Moot et al. 2003). A single spring application of $40 \mathrm{~kg}$ $\mathrm{N} / \mathrm{ha}$ as urea was applied to established ryegrass/white clover pastures, if needed, based on visual assessments. After the second winter, the lucerne paddocks were winter-sprayed (June/July) with paraquat at $500 \mathrm{~g}$ a.i./ ha and $900 \mathrm{~g}$ a.i./ha of atrazine. Soil tests $(15 \mathrm{~cm}$ depth $)$ occurred each March, and pasture samples for nutrient analysis were taken the following October to determine maintenance fertiliser requirements.

\section{Data collection}

Monthly monitoring of dry matter production was from 71 pasture cages $(600 \times 600 \times 300 \mathrm{~mm})$ across the three properties from 1 July 2008 to 30 June 2010 . Each month the caged pasture was cut to ground level with a pair of hand shears, weighed fresh on site and a sub sample analysed for dry matter content by ARL laboratories. After each cut the cage was shifted and placed on a pre-cut site, ensuring a fair representation of the area. Fifty-three of these cages were in lucerne, 11 in ryegrass/white clover and 7 on unimproved areas of resident vegetation (Table 4). For this analysis, unimproved areas are represented by parts of improved paddocks that were left undeveloped usually due to their shape or contour which made them difficult to access with large machinery.

Daily rainfall on farm was measured by the farm managers using a plastic rain gauge mounted near the house. For the 2009/2010 season local data from the NIWA CLIFLO database were used. Farm data and synchronous NIWA data were compared and suitable estimates for missing farm data were calculated.

\section{Data analysis}

Total dry matter (DM) yield was calculated from monthly harvests. When cuts were taken half way through the month, mean daily growth rates were proportioned to each month. Least squares linear regression was used to examine the relationship between dry matter production and water use, to calculate water use efficiency (WUE).

\section{Results}

\section{Annual yield}

Over the two growing seasons, total annual DM yields for the unimproved pastures were always less than $1.5 \mathrm{t} /$ ha compared with 3-5 $\mathrm{t} / \mathrm{ha}$ for improved ryegrass/white clover and between 4.2 and $8.4 \mathrm{t} / \mathrm{ha}$ for lucerne (Table 4). The ryegrass/white clover pasture yields at Hills Creek and The Styx in the 2008/2009 (wet) season were compromised because establishment only occurred in
Figure 1 Annual accumulated pasture growth and weekly rainfall from July 2008 to June 2010 at Hills Creek farm, Central Otago. Note: The ryegrass/white clover pasture was established during November 2008.

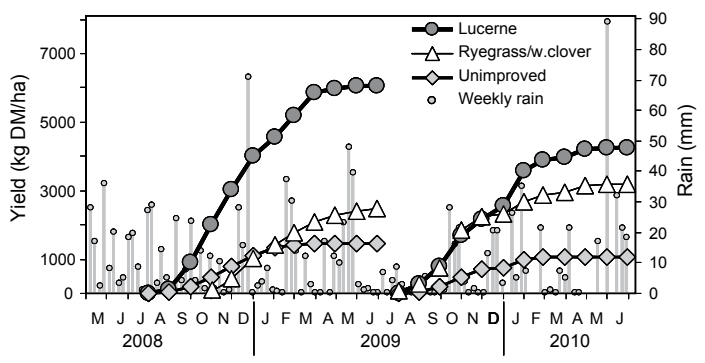

November 2008.

\section{Accumulated pasture yield and rainfall}

The pattern of annual yield accumulation differed among pasture types and this is described in detail for Hills Creek (Fig. 1). From 1 September to 31 December 2008, the lucerne produced 4 times that of the unimproved pasture. For all pastures, growth rate slowed in January 2009, before increasing again after $\sim 70 \mathrm{~mm}$ of rainfall in February. By the end of March, growth had almost stopped with total production for April-June limited to $20-350 \mathrm{~kg} \mathrm{DM} / \mathrm{ha}$ across all pasture types.

During the 2009 winter (1 May to 1 September), only $141 \mathrm{~mm}$ of rainfall was received at Hills Creek compared with $243 \mathrm{~mm}$ during the same period in 2008 . As a consequence the linear period of growth for the spring in 2009 was from 1 September until 31 October, or 2 months shorter than the previous year. During this period, the lucerne and new ryegrass/white clover pastures grew $1400-1600 \mathrm{~kg} \mathrm{DM} / \mathrm{ha}$ compared with $440 \mathrm{~kg} \mathrm{DM} / \mathrm{ha}$ for the resident browntop-based pastures. Rainfall events in December then increased the rate of dry matter accumulation before growth slowed again in January. There was little response to the rainfall from February onwards, despite $120+\mathrm{mm}$ of rainfall from 1 May 2010.

The potential soil moisture deficit (PSMD; Fig. 2) decreased as rainfall occurred. During the winter of 2008, the NIWA site at Middlemarch showed the PSMD decreased from 95 to $40 \mathrm{~mm}$. At the start of the spring growing season (shaded area) this deficit increased from 50 to $140 \mathrm{~mm}$, suggesting $90 \mathrm{~mm}$ of stored soil moisture had been used for plant growth. The Ranfurly site started the growing season at a PSMD of $15 \mathrm{~mm}$, and ended the spring growth period at $140 \mathrm{~mm}$, indicating plants used $125 \mathrm{~mm}$ of water of stored soil moisture for growth. A major difference between winter 2008 and winter 2009 was the lower rainfall in 2009. As a result, the PSMD for both sites were already between 100 and 
Figure 2 Potential soil moisture deficits (SMD) from May 2008 to June 2010. Shaded areas indicate the main spring growth period (NIWA, 2010).

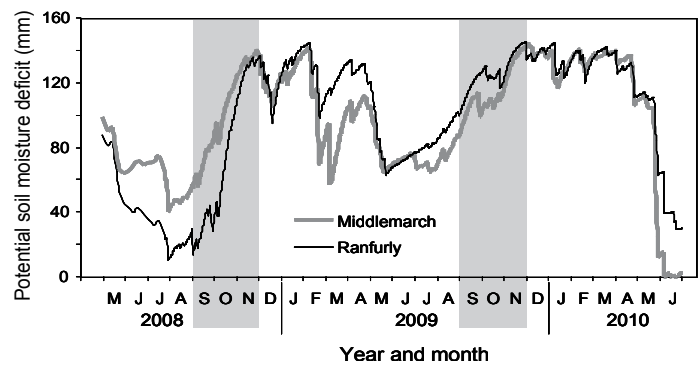

$120 \mathrm{~mm}$ at the start of spring growth. By the end of the spring growth period, the Middlemarch site only accrued an extra $40 \mathrm{~mm}$ of stored water and Ranfurly an extra $20 \mathrm{~mm}$ from the limited spring/summer rainfall (Fig. 1). For Middlemarch, winter rainfall in 2010 reduced the PSMD to zero which equates to full soil water storage or field capacity (Fig. 2).

\section{Water use efficiency}

From the data for accumulated dry matter yield $(\mathrm{kg}$ $\mathrm{DM} /$ ha), rainfall received (Table 4) and PSMD (Fig. 2), the water use efficiency (WUE) was calculated (Table 5). This is presented in detail for the Hills Creek site (Fig. 3). At Hills Creek WUE for lucerne was $12.6 \mathrm{~kg}$ $\mathrm{DM} / \mathrm{ha} / \mathrm{mm}$ during spring 2009 and $18.3 \mathrm{~kg} \mathrm{DM} / \mathrm{ha} /$ $\mathrm{mm}$ for Huntleigh during spring 2008. WUE for the unimproved pasture ranged from 0 to $3.7 \mathrm{~kg} \mathrm{DM} / \mathrm{ha} /$ $\mathrm{mm}$ at the different sites. The lucerne at the Styx had the highest WUE of all the sites with $24.6 \mathrm{~kg} \mathrm{DM} / \mathrm{ha} /$ $\mathrm{mm}$ during the summer 2008. The WUE for ryegrass/ white clover pastures during the 2009/2010 season ranged from 2.6 to $18.8 \mathrm{~kg} \mathrm{DM} / \mathrm{ha} / \mathrm{mm}$.

\section{Discussion}

\section{Impact of lime on Soil pH}

On these Central Otago farms pasture productivity was improved at least four fold by the correction of nutrient deficiencies and the introduction of improved pasture
Figure 3 Pasture yield in relation to water use (rain plus stored soil water) for Hills Creek farm, Central Otago, from July 2008 to May 2010. Vertical broken lines demarcate, from left, the winter (July and August), spring (September, October and November), summer (December, January and February) and autumn (March, April and May) growth periods. Regression lines are shown for each season's data excluding winter. The values of the slopes for the regression lines indicate the water use efficiency (WUE) and are presented in Table 3. Note: The ryegrass/white clover pasture was established during November 2008.



species. The unimproved pastures all yielded less than $1.5 \mathrm{t} \mathrm{DM} / \mathrm{ha}$ on soils that had a $\mathrm{pH}$ of $<5.2$. This low $\mathrm{pH}$ was addressed by the application of lime to reduce soil aluminium levels to $<1.5 \mathrm{mg} / \mathrm{kg}$. There is a strong relationship between soil $\mathrm{pH}$ and aluminium levels in many high country soils (Moir \& Moot 2010, this volume). The addition of sufficient lime to increase the soil $\mathrm{pH}$ to at least 5.8 is required to enable aluminium sensitive species, such as lucerne, to be grown (Edmeades et al. 1983). The advantage of creating a soil environment that enables improved pastures to

Table 4 Annual rainfall $(\mathrm{mm})$ recorded at three farms over 2 years and pasture dry matter yield $(\mathrm{kg} / \mathrm{ha})$ from three pasture types in the Maniototo region of Central Otago. The number of paddocks monitored (= sample size) are shown in parentheses.

\begin{tabular}{|c|c|c|c|c|c|}
\hline Farm & Date & Rain & Lucerne & $\begin{array}{c}\text { Ryegrass } \\
\text { white clover }\end{array}$ & Unimproved \\
\hline \multirow[t]{2}{*}{ Hills Creek } & July 2008-June 2009 & 596 & $6050(18)$ & $2460^{2}(3)$ & $1470(2)$ \\
\hline & July 2009-June 2010 & $466^{1}$ & 4250 (18) & $3180(3)$ & $1080(2)$ \\
\hline \multirow[t]{2}{*}{ Huntleigh } & July 2008-June 2009 & 507 & 6440 (19) & - & $970(2)$ \\
\hline & July 2009-June 2010 & $537^{1}$ & 4760 (19) & $2940^{2}(4)$ & $400(2)$ \\
\hline \multirow[t]{2}{*}{ Styx } & July 2008-June 2009 & 499 & $8340(16)$ & $5070(4)$ & $130(3)$ \\
\hline & July 2009-June 2010 & $415^{1}$ & $8480(16)$ & $5330(4)$ & $130(3)$ \\
\hline
\end{tabular}

${ }^{1}$ Rain for the respective properties in May and June 2010 was 165, 235 and $99 \mathrm{~mm}$ but no growth response in any pastures was observed from this.

${ }^{2}$ Ryegrass/white clover pastures sown in November of their respective years. 
Table 5 Water use efficiency (WUE; $\mathrm{kg} \mathrm{DM} / \mathrm{ha} / \mathrm{mm}$ ) during spring (September, October, November), summer (December, January, February) and autumn (March, April, May) from 2008 - 2010 for pastures grown on three farms in the Maniototo region of Central Otago. Note: WUE was calculated using rainfall plus the soil water used, the latter estimated using potential soil moisture deficits (SMD) from NIWA meteorological stations at Ranfurly (for Hills Creek and Styx) and Middlemarch (for Huntleigh). Regression goodness of fit is indicated by the coefficient of determination $\left(R^{2}\right)$. Missing data (-) are from when pastures were not yet established.

\begin{tabular}{|c|c|c|c|c|c|}
\hline \multirow[b]{2}{*}{ Farm } & \multirow[b]{2}{*}{ Season } & \multicolumn{3}{|c|}{ Pasture type } & \multirow[b]{2}{*}{ Unimproved } \\
\hline & & $\mathrm{R}^{2}$ & Lucerne & $\begin{array}{l}\text { Ryegrass/ } \\
\text { white clover }\end{array}$ & \\
\hline \multirow[t]{6}{*}{ Hills Creek } & Spring 2008 & $>0.97$ & 12.6 & - & 3.3 \\
\hline & Summer 2008-09 & $>0.96$ & 12.3 & 7.8 & 3.7 \\
\hline & Autumn 2009 & $<0.90$ & 6.0 & 4.5 & 0.5 \\
\hline & Spring 2009 & $>0.99$ & 14.9 & 16.0 & 5.0 \\
\hline & Summer $2009-10$ & $>0.93$ & 12.6 & 4.8 & 2.7 \\
\hline & Autumn 2010 & $<0.72$ & 5.1 & 4.1 & 0.3 \\
\hline \multirow[t]{6}{*}{ Huntleigh } & Spring 2008 & $>0.95$ & 18.3 & - & 3.7 \\
\hline & Summer 2008-09 & $>0.92$ & 8.3 & - & 1.8 \\
\hline & Autumn 2009 & $<0.88$ & 8.6 & - & 0.3 \\
\hline & Spring 2009 & $>0.90$ & 17.3 & - & 2.5 \\
\hline & Summer $2009-10$ & $<0.90$ & 14.0 & 11.4 & 0.0 \\
\hline & Autumn 2010 & $>0.97$ & 2.8 & 6.5 & 0.1 \\
\hline \multirow[t]{6}{*}{ Styx } & Spring 2008 & $>0.97$ & 17.4 & 13.6 & - \\
\hline & Summer 2008-09 & $>0.93$ & 24.6 & 8.2 & 3.6 \\
\hline & Autumn 2009 & $>0.95$ & 10.0 & 9.4 & 0.6 \\
\hline & Spring 2009 & $>0.90$ & 19.3 & 18.8 & 0.3 \\
\hline & Summer $2009-10$ & $>0.90$ & 31.0 & 8.2 & 0.5 \\
\hline & Autumn 2010 & $<0.30$ & 6.0 & 2.6 & 0.1 \\
\hline
\end{tabular}

be grown was apparent at all sites. Fig. 1 shows the superiority of lucerne over unimproved and improved pastures in both years. In 2008/2009 (wet) the $596 \mathrm{~mm}$ of rainfall produced $6.1 \mathrm{t} \mathrm{DM} /$ ha lucerne compared with $2.8 \mathrm{t} \mathrm{DM} / \mathrm{ha}$ of an establishing perennial ryegrass pasture. In 2009/2010 (dry) the pasture also produced about 3.1 tonnes of biomass which was 3 times that produced by the unimproved pasture. Assuming these pasture responses are typical for the environment would then allow the economic feasibility of pasture renovation and fertiliser inputs to be assessed in these extensive pastoral systems.

\section{Yield and rainfall}

The total annual production from improved pastures was dependent on the rainfall received once growth stopped in the autumn, due to cool temperatures, and until it started in the following spring. For example, from the 1 May until the 1 September 2008 there was $243 \mathrm{~mm}$ of rainfall with little pasture growth. Effectively this winter fallow provided $\sim 100 \mathrm{~mm}$ of stored soil moisture (Fig. 2) that assisted spring pasture production from September. Additional in-season rainfall then maintained at least some growth between rainfall events until all of the stored soil moisture had been utilised. For the unimproved browntop dominant pasture, growth essentially stopped in January compared with March for the lucerne (Fig. 1). Similarly, in 2009/2010 (dry) the unimproved pasture growth stopped in January. However, in this season the lack of winter and spring-summer rainfall meant the lucerne and improved pastures also ceased growth at this time. Specifically, from 1 May to 1 September 2009, only 141 $\mathrm{mm}$ of rain fell which produced $45-55 \mathrm{~mm}$ of available soil moisture on 1st September. A further $136 \mathrm{~mm}$ of rain was recorded to the 1 January with negligible summer rainfall. As a consequence the yield advantage for lucerne was only $1.1 \mathrm{t} \mathrm{DM} / \mathrm{ha}$ over the ryegrass pastures. In autumn 2010 , the $120+\mathrm{mm}$ of rainfall did not result in a pasture growth response, but has reduced the PSMD to $0 \mathrm{~mm}$ (Fig. 2) suggesting the soil was fully recharged for spring 2010.

The importance of winter rainfall and subsequently spring growth was quantified by calculating the WUE. An estimate of the amount of soil water used was made from the change in soil moisture deficit at the nearest NIWA station (Fig. 2). For Hills Creek, using Ranfurly data (NIWA) for spring 2008, the soil contributed about $120 \mathrm{~mm}$ of water in addition to the spring rainfall. Using these values, the WUE of the lucerne was 
calculated at $16.0 \mathrm{~kg} \mathrm{DM} / \mathrm{ha} / \mathrm{mm}$, and comparable with other reports (Moot et al. 2008). The WUE was $3.7 \mathrm{~kg}$ $\mathrm{DM} / \mathrm{ha} / \mathrm{mm}$ for the unimproved pasture. The difference in winter soil water storage is highlighted by the change in soil moisture deficit in 2009. However, it must be remembered that the NIWA data on soil moisture can only approximate the actual soil moisture on any given paddock because of different soil depths, pasture rooting depth, and differences in rainfall and potential evaporation between sites.

\section{On farm calculation of WUE}

The calculations made for WUE could be made for any site in the country for which meteorological data are available. These on-farm WUE calculations rely on accurate rainfall data and preferably a close estimate of the contribution of stored soil water by using nearby NIWA climate station data. The process then adds a percentage of winter rainfall to the following growing season rainfall or use of an on farm measurement of soil moisture status. Once pasture growth stops in autumn/winter, transpiration also stops so soil moisture recharge occurs. The NIWA soil moisture deficit (SMD) data allows for potential evapotranspiration over winter when there is still soil evaporation and run-off so not all winter rain becomes stored soil moisture. The level of this recharge is dependent on the water holding capacity of the soil before field capacity is reached and drainage occurs (Moot et al. 2008).

Of note was the spring WUE of the new ryegrass/ white clover pasture at Hills Creek that was similar to the lucerne in $2009 / 2010$. This probably reflects the higher legume content of these establishing pastures. The importance of maximising spring growth has previously been highlighted by Moot et al. (2008). In their studies, the WUE in spring was higher than in any other season and has been attributed to differences in herbage nitrogen content (Tonmukayakul et al. 2010).

\section{Conclusion}

The development of 18000 ha in Central Otago has quantified, on a commercial scale, the production advantages to improved species over the resident vegetation and related these to the soil water and its use. Importantly, rectifying soil nutrient requirements coupled with the introduction of $\mathrm{N}$ fixing plants more than trebled the production in this low rainfall, cold winter environment.

\section{ACKNOWLEDGEMENTS}

D J Moot acknowledges support for dryland pasture research from Beef + Lamb New Zealand Ltd through the FoRST Pastoral 21 programme.

\section{REFERENCES}

Avery D.; Avery, F.; Ogle, G.I.; Wills, B.J.; Moot, D.J. 2008. Adapting farm systems to a drier future. Proceedings of the New Zealand Grassland Association 70: 13-18.

Brown, H.E, Moot, D.J.; Lucas, R.J.; Smith, M. 2006. Sub clover, cocksfoot and lucerne combine to improve dryland stock production. Proceedings of the New Zealand Grassland Association 68: 109-115.

Edmeades, D.C.; Smart C.E.; Wheeler, D.M. 1983. Aluminium toxicity in New Zealand soils: preliminary results on the development of diagnostic criteria. New Zealand Journal of Agricultural Research 26: 493501.

Mills A.; Smith, R.J.; Moot, D.J. 2008. Dryland pasture yields and botanical composition over 5 years under sheep grazing in Canterbury. Proceedings of the New Zealand Grassland Association 70: 37-44.

Moir J.L.; Moot D.J. 2010. Soil pH, exchangeable aluminium and lucerne yield responses to lime in a South Island high country soil. Proceedings of the New Zealand Grassland Association 72: 191-196.

Moot, D.J.; Brown, H.E.; Teixiera, E.I.; Pollock, K. 2003. Crop growth and development affect seasonal priorities for lucerne management. Legumes for dryland pastures. Grassland Research and Series Practice Series 11: 201-208.

Moot, D.J.; Brown, H.E.; Pollock, K.; Mills, A. 2008. Yield and water use of temperate pastures in summer dry environments. Proceedings of the New Zealand Grassland Association 70: 51-58.

New Zealand Soil Bureau 1968: General survey of the soils of the South Island, New Zealand. New Zealand Soil Bureau Bulletin 27: 11, 13.

NIWA: CliFlo climate database. http://www.cliflo.niwa. co.nz/

Radcliffe, J.E.; Baars, J.A. 1987. The productivity of temperate grasslands. pp. 7-17. In: Ecosystems of the World Managed Grasslands: Analytical Studies. Eds. Snaydon, R.W. Elsevier Science Publishers, Amsterdam.

Tonmukayakul, N.; Moot D. J.; Mills, A.M. 2010. Spring water use efficiency of six dryland pastures in Canterbury. Agronomy New Zealand (In Press). 